\title{
EFFECTS OF GLUCOSAMINE ON THE TIBIAL EPIPHYSEAL DISK OF OVARIECTOMIZED RATS: MORPHOLOGIC AND MORPHOMETRIC ANALYSIS
}

\author{
Carla C Maganhin ${ }^{1}$, Olga Correa ${ }^{1}$, Regina CT Gomes ${ }^{1}$, Ricardo Simões ${ }^{2}$, Edmund \\ C Baracat ${ }^{3}$, José Maria Soares-Jr²
}

\begin{abstract}
Maganhin CC, Correa O, Gomes RCT, Simões R, Baracat EC, Soares-Jr JM. Effects of glucosamine on the tibial epiphyseal disk of ovariectomized rats: morphologic and morphometric analysis.Clinics. 2007;62(5):607-12.
\end{abstract}

OBJECTIVE: The aim of this study was to analyze the effect of glucosamine sulfate on the tibial epiphyseal disk of the ovariectomized rats.

METHODS: After ovariectomy (OVx), 28 female rats were randomly divided into 4 experimental groups with 7 animals each, treated as follows: OVx 21 -vehicle $(\mathrm{NaCl} 0.9 \%) 0.5 \mathrm{~mL} /$ day) for 21 days; OVx GS21—230 mg/kg/day glucosamine sulphate for 21 days; $\mathrm{OVx} 45$ — treated with $\mathrm{NaCl} 0.9 \%$ as above for 45 days; and OVx GS45—230 mg/kg/day glucosamine sulphate for 45 days. Seven intact animals in the proestrous phase were used as controls (CG). Upon treatment completion, the animals were sacrificed and the left knee joint was dissected and prepared for histological analysis.

RESULTS: The percentage of remaining cartilage in new bone of the CG; that found in THE OVx GS45 group was significantly less than that of the OVx 21, OVx GS21, and OVx 45 groups. The percentage of trabecular bone in proestrous animals was the highest. The OVx GS45 group showed higher values compared with the other ovariectomized groups. These results were paralleled by the findings regarding the cells of the proliferative zone, since the CG had the highest values, and the values of the OVx GS45 group were greater than those of the OVx 21, OVx GS21, and OVx 45 groups.

CONCLUSION: Our studies suggested that glucosamine may stimulate tibial cartilage and bone growth after ovariectomy in rats.

KEY-WORDS: Glucosamine. Epiphyseal disk. Tibia. Ovariectomy. Female rats.

\section{INTRODUCTION}

Osteoporosis is a serious problem for postmenopausal and elderly women, and it is known that estrogen deficiency plays a causative role in its development. ${ }^{1}$ Estrogen can act directly or indirectly on osteoblasts and osteoclasts through estrogen receptor-mediated mechanisms, ${ }^{2}$ such as inhibition of production of bone-resorptive cytokines from bone

1. Morphology - Federal University of São Paulo - São Paulo, SP/Brazil 2. Gynecology- Federal University of São Paulo - São Paulo, SP/Brazil 3. Gynecology - University of São Paulo Medical School of Medicine, São Paulo, SP/Brazil

Email: jsoares415@hotmail.com

Received for publication on April 29, 2007

Accepted for publication on May 16, 2007 marrow stromal cells, ${ }^{3}$ direct inhibition of the activity of osteoclasts, ${ }^{4}$ enhancement of osteoblast proliferation, and stimulation of secretion of bone matrix proteins by osteoblasts. ${ }^{5}$ In fact, a definite anabolic effect on bone formation can be found in estrogen-deficient animal models. ${ }^{6,7}$ Not surprisingly, estrogen therapy has been widely accepted as an effective treatment in postmenopausal women for preventing reduction of the bone mineral density. ${ }^{8}$ However, prolonged estrogen replacement therapies have proved to increase the risks of breast and uterine cancer., ${ }^{9,10}$ In addition, bone mineral density may decline after discontinuation of short-term menopausal hormone therapy (MHT), which would increase the fracture risks. Also, past-MHT users are osteopenic just as are non-users. ${ }^{11}$ Therefore, alternative osteoporosis-targeted treatments with milder ad- 
verse reactions would be highly desirable.

Glucosamine is a nontoxic, bioavailable, naturally occurring component of the cartilage matrix. ${ }^{12}$ Glucosamine has been shown to have a number of favorable effects on cartilage metabolism in vitro, including a reduction in articular cartilage breakdown and stimulation of synthesis of matrix components by chondrocytes. ${ }^{13}$ Given orally to osteoarthritic patients, glucosamine has been shown to decrease joint pain and improve mobility. ${ }^{14}$ Unfortunately, the available information regarding the effect of such treatment on bone morphology is rather limited. It has been found that the administration of glucosamine produces a significant reduction in left hind paw swelling following onset of arthritis in rats along with a lesser degree of edema and new bone formation. ${ }^{15}$ In addition, the Canadian Multicenter Osteoporosis Study showed that the weighted values for bone mass density (BMD) of men using glucosamine were lower than those of men not using it. ${ }^{16}$ The opposite was seen in women, since those who were under glucosamine treatment had a higher mean BMD than their untreated counterparts. ${ }^{16}$ Also, a few studies have shown that a polymer of $\mathrm{N}$-acetylglucosamine and glucosamine may induce the cellular response for bone regeneration and increase the cellular growth and proliferation in vitro. ${ }^{17,18}$

In the present study, female rats were used as an animal model for investigating the effects of an oral glucosamine sulphate preparation on the joint bone morphology of estrogen-deprived rats.

\section{MATERIALS AND METHODS}

\section{Animals and treatments}

The local institution's guidelines for the care and use of the animals were followed; these guidelines comply with those of the Canadian Council on Animal Care ${ }^{19}$ and the NIH's Institutional Animal Care and Use Committee Guidebook. The experimental protocol was approved by the local Ethics Committee on Animal Experimentation. Female adult, virgin, EPM-1 Wistar rats were selected after 3 regular consecutive estrous cycles and kept under specific pathogen-free conditions at a constant day/night cycle (lights on 07:00-19:00). Animals were fed Purina ${ }^{\circledR}$ pelleted rat food and tap water ad libitum.

Seven animals in the proestrous phase were assigned to the control group (CG), and 28 rats after being ovariectomized (OVx) were randomly divided into 4 experimental groups with 7 animals each: OVx 21-treated with vehicle $(\mathrm{NaCl} 0.9 \%)$ for 21 days; OVx GS21-treated with glucosamine sulphate (GS) (Zodiac Tecnofarma,
Pindamonhangaba, Brazil, $230 \mathrm{mg} / \mathrm{kg}$, ip) for 21 days; OVx 45 - treated with vehicle $(\mathrm{NaCl} 0.9 \%)$ for 45 days; and $\mathrm{OVx}$ GS45 - treated with glucosamine sulphate $(230 \mathrm{mg} / \mathrm{kg}$, ip) for 45 days. The glucosamine sulfate and vehicle treatments were started on the 21st day after ovariectomy.

At the end of treatment, all animals were sacrificed under anesthesia (xylazine $20 \mathrm{mg} / \mathrm{kg}$ plus ketamine $100 \mathrm{mg} /$ $\mathrm{kg}$, ip); then, the left tibia was dissected and fixed in buffered formaldehyde $10 \%$ at room temperature for 24 hours. After treatment with $7 \%$ ethylenediaminetetraacetic acid (EDTA), the decalcified joint matrix was embedded in paraffin and cut into $5 \mu \mathrm{m}$ histological sections that were stained with hematoxylin and eosin.

\section{Histomorphometric analysis}

After the histological procedures, morphometric measurements were performed using digitalized images obtained directly from the light microscope via a videocamera and stored in magnetic medium. Measurements were automatically performed using the Imagelab-Softium ${ }^{\circledR}$ software (São Paulo, Brazil). The analyses were performed in 10 microscopical fields per histological section from a total of 4 histological sections per animal. The normal chondrocytes of the epiphyseal disk in non ovariectomized female rats (CG) were organized in well-defined regions: resting cartilage zone, proliferative zone, hypertrophic zone, calcified zone, and ossification zone.

The newly formed bone was defined as the measured osseous structure from the end of epiphyseal disk to the Weibel reticule. In this area, we calculated the remaining cartilage (resting state), the trabecular bone, and the bone marrow (Figure 1). In addition, cell counting was performed

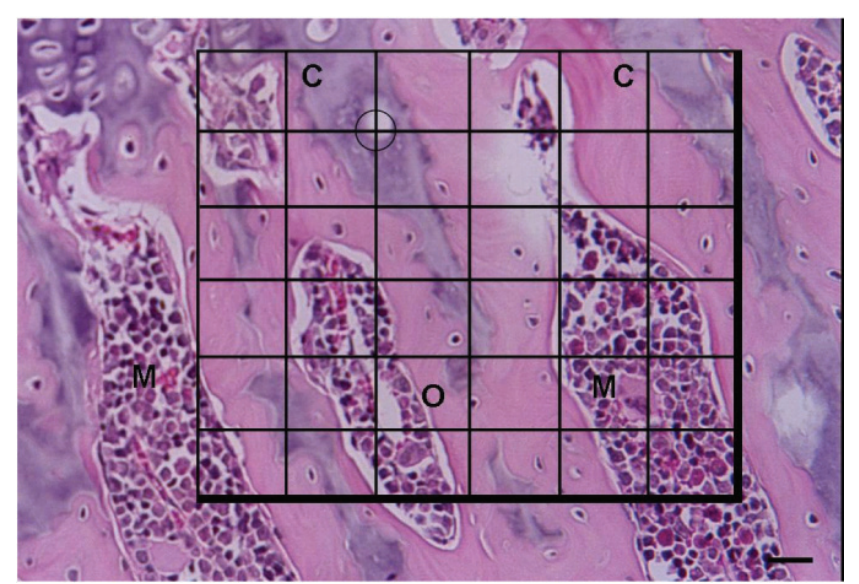

Figure 1 - Photomicrography showing the Weibel reticule under the epiphyseal disk of a female rat in the proestrous. The thick lines were representative of noncounted lines. The circle shows 1 of the 36 points of intersection for measurements. $\mathrm{B}$, trabecular bone; $\mathrm{C}$, remaining cartilage; M, bone marrow. Hemotoxylin-eosin (100x). Bar $=10 \mu \mathrm{m}$. 
at the proliferative zone of the epiphyseal disk (30 columns per animal). In order to avoid some overcounting due to the 'reticular extremity effect' reported by Gundersen, ${ }^{20} 2$ lines of each reticular extremity were not considered in the calculations. $^{21}$

\section{Statistical analysis}

Data from the morphometric analyses are reported as mean \pm standard deviation (SD). The histomorphometrical results (remaining cartilage, bone marrow, trabecular bone, and proliferative zone) were analyzed by the Barlett's test and 1-way analysis of variance followed by Tukey's post hoc test, with the level of significance set at $P<.05$. The data of every parameter were confirmed to follow a Gaussian distribution.

\section{RESULTS}

\section{Histomorphology}

The ovariectomized groups treated with vehicle (OVx 21 and OVx 45) showed an increased resting cartilage zone and a significant shortening of the proliferative zone. This change was more intensive in the animals treated with vehicle for 45 days than in the other groups. In fact, the proliferative zone had a low number of disorganized cuboid cells. In the glucosamine-treated groups, the treatment for 21 days did not affect the resting cartilage and proliferative zones. The histomorphology of this group was similar to OVx 21 (vehicle treatment), but it was worse than the nonovariectomized rat group. The animals treated during 45 days with glucosamine showed an improvement in the proliferative zone with respect to the other ovariectomized animals; however, this increase was lower than that seen in proestrous animals.

In the glucosamine-treated groups, the treatment for 21 days did not affect the resting cartilage and proliferative zones. The histomorphology of this group was similar to OVx 21. The animals treated during 45 days with glucosamine showed an improvement in the proliferative zone with respect to the other ovariectomized animals; however, this increase was lower than that seen in proestrous animals (Figure 2).

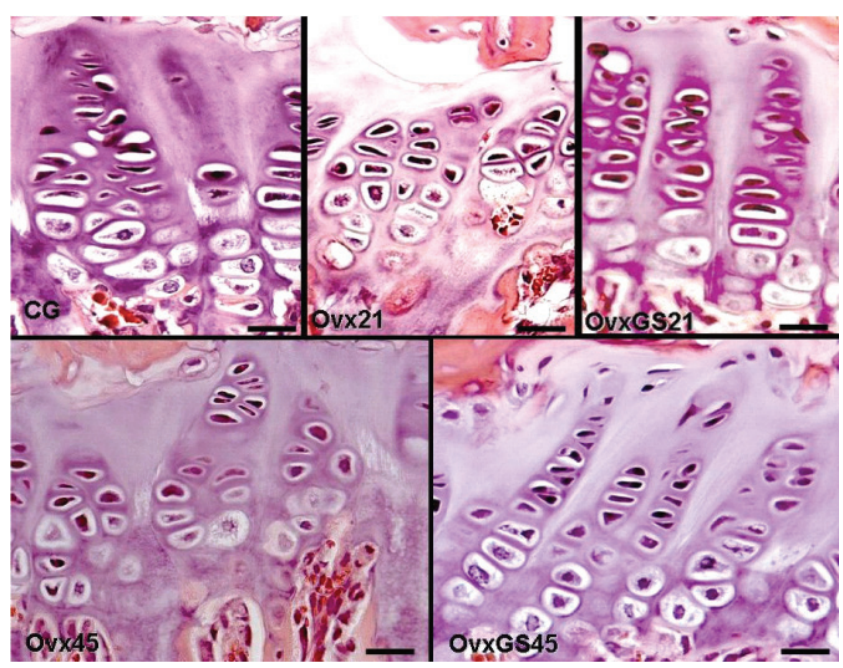

Figure 2 - Photomicrography of rat tibial epiphyseal disk showing the remaining cartilage and the proliferative zone of each group: CG (salinetreated, intact, proestrus); OVx 21 (control OVx, 21 days saline); OVx GS21 (OVx, 21 days glucosamine $230 \mathrm{mg} / \mathrm{kg}$ OVx 45 (control OVx, 45 days saline), and OVx GS45 (OVx, 45 days glucosamine $230 \mathrm{mg} / \mathrm{kg}$ ). Hemotoxylin-eosin; $\mathrm{OVx}=$ animals used 21 days after bilateral ovariectomy (400x). Bar $=10 \mu \mathrm{m}$.

\section{Histomorphometric results}

Table 1 shows the values of the histomorphological data of the remaining cartilage, trabecular bone, bone marrow, and the cell number in the proliferative zone of the tibial epiphyseal disk. The percentage of remaining cartilage in new bone of the $\mathrm{CG}$ was the lowest $(13.6 \pm 1.5, P<.01)$. Results from the OVx GS45 group $(17.8 \pm 2.8, P<.05)$ were significantly lower than those from the OVx 21 (21.5 $\pm 2.1)$, OVx GS21 (20.7 \pm 1.1$)$, and OVx $45(22.7 \pm 1.3)$ groups. No difference was found among the groups regarding the tibial bone marrow. The percentage of trabecular bone in proestrous phase animals (CG) had the highest values $(28.1 \pm 2.4, P<.01)$, and that for the OVx GS45 group $(26.9 \pm 2.2, P<.05)$ was higher than the other ovariectomized groups. The cells of the proliferative zone presented similar results: $C G$ had the highest values $(195.5 \pm 11.9$, $P<.01)$, and the OVx GS45 group $(149.5 \pm 4.2, P<.05)$

Table 1 - Histomorphometrical data of knee joint bone preparations using a female rat model of osteoporosis.

\begin{tabular}{|c|c|c|c|c|c|}
\hline & CG & OVx 21 & $\begin{array}{c}\text { Animal groups } \\
\text { OVx GS21 }\end{array}$ & OVx 45 & OVx GS45 \\
\hline Remaining cartilage $(\%)$ & $13.6 \pm 1.5^{*}$ & $21.5 \pm 2.1$ & $20.7 \pm 1.1$ & $22.7 \pm 1.3$ & $17.8 \pm 2.8^{* *}$ \\
\hline Bone marrow $(\%)$ & $58.2 \pm 5.8$ & $57.4 \pm 4.7$ & $55.1 \pm 4.8$ & $57.0 \pm 7.5$ & $55.3 \pm 4.7$ \\
\hline Trabecular bone $(\%)$ & $28.1 \pm 2.4^{*}$ & $21.1 \pm 1.9$ & $24.3 \pm 2.8$ & $20.3 \pm 1.1$ & $26.9 \pm 2.2^{* *}$ \\
\hline Proliferative zone (mean of cells in $250 \mu \mathrm{m}^{2}$ ) & $195.5 \pm 11.9^{*}$ & $95.4 \pm 21.2$ & $105.8 \pm 4.7$ & $89.3 \pm 12.2$ & $149.5 \pm 4.2^{* *}$ \\
\hline
\end{tabular}

${ }^{*} P<.01$ compared with other groups; ${ }^{* *} P<.05$ compared with OVx 21 , OVx GS21, and OVx 45 
presented values significantly higher than those found in the OVx $21(95.4 \pm 21.2)$, OVx GS21 (105.8 \pm 4.7$)$, and OVx $45(89.3 \pm 12.2)$ groups.

\section{DISCUSSION}

After menopause, the reduction in bone mass is a matter of great medical concern. Hormone therapy is used for preventing osteoporosis-related fracture. ${ }^{19}$ However, large clinical trials, such as HERS and WHI, showed that postmenopausal women orally treated for long periods with conjugated equine estrogens $(0.625 \mathrm{mg} /$ day $)$ associated with medroxyprogesterone $(2.5 \mathrm{mg} /$ day $)$ were at a relative risk of developing breast cancer and cardiovascular disease. ${ }^{22}$ Consequently, the number of hormone therapy prescriptions actually decreased after those studies were published. ${ }^{23}$ Therefore, it has been realized that new approaches for maintain the bone mass in postmenopausal women are needed. Herein, our data suggest that glucosamine sulphate may affect the bone mass of ovariectomized rats. It must be considered, however, that the doses of glucosamine used with our animals were higher ( 8 times) than those used in humans, mostly because of the species-specific differences in the metabolic rates. ${ }^{24}$ Further studies are necessary to evaluate the effect of different doses of glucosamine for the same period with respect to a similar action on the rat tibial epiphyseal disk.

Ovariectomy is a factor that may determine a decrease in bone growth and deleterious changes in epiphyseal disks. These bone alterations are similar to those found in senile rats. ${ }^{25}$ The reason for these phenomena is the reduction of the cell mass in proliferative zones and disorganization of the bone matrix. ${ }^{26}$ Our results conceivably suggest that the bone matrix of epiphyseal disks may be a target for the glucosamine sulphate effects. However, this effect may occur after a prolonged period of estrogen level decrease. This fact may explain the reason for not finding a difference between the glucosamine-treated and nontreated rats after 21 days after ovariectomy.

In clinical trials, the administration of glucosamine has produced a beneficial change in the osteoarthritis, demonstrating a chondroprotective effect that results in a significant delay in the progression of the disease. ${ }^{24,27-29}$ Accordingly, glucosamine-treated patients presented better bone mass with regard to untreated postmenopausal patients. ${ }^{29}$ The expanded bone mass would be due to the fact that those patients are more physically active more due to the improvements in inflammatory processes and pain. ${ }^{28}$

Our results confirm findings by other authors that glucosamine had beneficial effects in rats on the tibial surface, which was the structure selected for analysis in this study. Those authors suggested that glucosamine may act on the bone matrix..$^{30,31}$ In accordance with this view, in vitro studies have shown that glucosamine inhibits the effects of interleukin-1, although some authors state that the inhibiting dose is greater than the maximum serum level of glucosamine (absorption limit). ${ }^{32}$ Perhaps, glucosamine at normal tissue levels acts rather by stimulating the production of matrix components than by inhibiting the effects of interleukin- $1^{33}$. However, further studies are necessary to investigate the real mechanism of glucosamine on the rat bone and remaining cartilage after ovariectomy.

\section{ACKNOWLEDGMENT}

We would like to thank Prof. Hanna A. Rothschild for language review and Prof Oswaldo Alves Mora (In Memoriam) for designing this study.

\section{RESUMO}

Maganhin CC, Correa O, Gomes RCT, Simões R, Baracat EC, Soares-Jr JM. Efeitos da terapia de reposição hormonal estroprogestativa sobre o sistema de coagulação e de fibrinólise em mulheres na pós-menopausa. Clinics. 2007;62(5):607-12.

OBJETIVO: O alvo deste estudo foi analisar o efeito do sulfato de glicosamina no disco epifisário da tíbia em ratas ooforectomizadas.

MÉTODOS: Após a ooforectomia (OVx), 28 ratas foram aleatoriamente divididas em 4 grupos experimentais de 7 animais cada, tratados da seguinte maneira: OVx 21 - veículo $(0,5 \mathrm{ml}$ de $\mathrm{NaCl} 0.9 \%$ ip uma vez ao dia) por 21 dias;
OVx GS21 - $230 \mathrm{mg} / \mathrm{kg}$ peso corporal por dia de sulfato de glicosamina, 21 dias; OVx 45 - tratados com $\mathrm{NaCl} 0.9 \%$ igual ao grupo OVx 21, por 45 dias; e OVx GS45 - 230 $\mathrm{mg} / \mathrm{kg}$ peso corporal por dia com sulfato de glicosamina, 45 dias. Sete animais intactos, na fase de proestro, foram usados como controle (CG). Ao completar o tratamento, os animais foram sacrificados e a articulação do joelho esquerdo foi dissecada e preparada para análise histológica.

RESULTADOS: A porcentagem de cartilagem remanescente no novo osso do CG foi a menor. Os achados no grupo OVx GS45 foi significantemente menor do que no grupo OVx 21, OVx GS21 e OVx 45. A porcentagem de osso trabecular nos animais em pró-estro foi a maior. $\mathrm{O}$ grupo 
OVx GS45 mostrou valores maiores em relação aos outros grupos ooforectomizados. Esses resultados foram correspondentes aos achados em relação às células da zona proliferativa, desde que o CG teve os maiores valores e os valores do grupo OVx GS45 foram superiores aos dos grupos OVx 21, OVx GS21 e OVx 45.
CONCLUSÃO: Nossos estudos sugerem que a glicosamina pode estimular o crescimento da cartilagem e do osso tibial após a ooforectomia em ratas.

UNITERMOS: Glicosamina. Disco epifisário. Tíbia. Ooforectomia. Ratas.

\section{REFERENCES}

1. Boling EP. Gender and osteoporosis: similarities and sex-specific differences. J Gend Specif Med. 2001;4:36-43.

2. Christgau S, Tanko LB, Cloos PA, Mouritzen U, Christiansen C, Delaisse $\mathrm{JM}$, et al. Suppression of elevated cartilage turnover in postmenopausal women and in ovariectomized rats by estrogen and a selective estrogenreceptor modulator (SERM). Menopause. 2004;11:508-18.

3. Sykes DB and Kamps MP. Estrogen-regulated conditional oncoproteins: tools to address open questions in normal myeloid cell function, normal myeloid differentiation, and the genetic basis of differentiation arrest in myeloid leukemia. Leuk Lymphoma. 2003;44:1131-9.

4. Kenny AM and Raisz LG. Mechanisms of bone remodeling: implications for clinical practice. J Reprod Med. 2002;47:63-70.

5. Parikka V, Vaananen A, Risteli J, Salo T, Sorsa T, Vaananen HK, et al. Human mesenchymal stem cell derived osteoblasts degrade organic bone matrix in vitro by matrix metalloproteinases. Matrix Biol. $2005 ; 24: 438-47$.

6. Westerlind KC, Wakley GK, Evans GL, Turner RT. Estrogen does not increase bone formation in growing rats. Endocrinology. 1993;133:2924-34.

7. Hukkanen M, Platts LA, Lawes T, Girgis SI, Konttinen YT, Goodship $\mathrm{AE}$, et al. Effect of nitric oxide donor nitroglycerin on bone mineral density in a rat model of estrogen deficiency-induced osteopenia. Bone. 2003;32:142-9.

8. Delaney MF. Strategies for the prevention and treatment of osteoporosis during early postmenopause. Am J Obstet Gynecol. 2006;194:S12-23.

9. Conner P. Breast response to menopausal hormone therapy-aspects on proliferation, apoptosis and mammographic density. Ann Med 2007;39:28-41.

10. Russo IH and Russo J. Primary prevention of breast cancer by hormoneinduced differentiation. Recent Results Cancer Res. 2007;174:111-30.

11. Aubertin-Leheudre M, Melancon MO, Chaput JP, Dionne IJ. Past-users of HRT are osteopenic four months after discontinuation: an observational and cross-sectional study. J Women Aging. 2006;18:1929.

12. Setnikar I, Giacchetti C, Zanolo G. Pharmokinetics of glucosamine in the dog and in man. Drug Res. 1986;36:729-35.

13. Bassleer C, Henrotin Y, Franchimont P. In vitro evaluation of drugs proposed as chondroprotective agents. Intl J Tiss Reac. 1992;14:231-41.

14. McCarthy MF. The neglect of glucosamine for the treatment of osteoarthritis a personal perspective. Med Hypotheses. 1989;42:323-7.
15. Tsi D, Khow A, Iino T, Kiso Y, Ono H. Effect of Brand's glucosamine with essence of chicken on collagen-induced arthritis in rats. Life Sci. 2003;73:2953-62.

16. Hopman WM, Towheed TE, Gao Y, Berger C, Joseph L, Vik SA, et al. Prevalence of and factors associated with glucosamine use in Canada. Osteoarthritis Cartilage. 2006;14:1288-93.

17. Matsunaga T, Yanagiguchi K, Yamada S, Ohara N, Ikeda T, Hayashi Y Chitosan monomer promotes tissue regeneration on dental pulp wounds. J Biomed Mater Res A. 2006; 76:711-20.

18. Lopez-Lacomba JL, Garcia-Cantalejo JM, Sanz Casado JV, Abarrategi A, Correas Magana V, Ramos V. Use of rhBMP-2 activated chitosan films to improve osseointegration. Biomacromolecules. 2006;7:792-8.

19. Olfert ED, Cross BM, McWilliam AA Canadian council on animal care's guide to the care and use of experimental animals. Ottawa Canada: Bradda Printing Services; 1993

20. Gundersen HJ. Notes on the estimation of the numerical density of arbitrary profiles: the edge effect. J Microscopy. 1977;111:219-27.

21. Mandarim-de-Lacerda CA. Sterological tools in biomedical research. Ann Acad Bras Ciên. 2003;75:469-86.

22. Randolph JF Jr. Women's Health Initiative Estrogen/Progestin and HERS II Trials. Be careful of what you wish for: putting the WHI Estrogen/ Progestin and HERS II Trials in perspective. Medscape Womens Health. 2002;7:7.

23. Reeves GK, Beral V, Green J, Gathani T, Bull D; Million Women Study Collaborators. Hormonal therapy for menopause and breast-cancer risk by histological type: a cohort study and meta-analysis. Lancet Oncol. 2006;7:910-8.

24. van Blitterswijk WJ, van de Nes JC, Wuisman PI. Glucosamine and chondroitin sulfate supplementation to treat symptomatic disc degeneration: biochemical rationale and case report. BMC Complement Altern Med. 2003;3:2

25. Roach HI, Menta G, Oreffo ROC, Carke NMD, Cooper C. Temporal analysis of rat growth plates: cessation of growth with age despite presence of physis. J Hist Cytochem. 2003;51:373-83.

26. Kuhn JL, Delacey JH, Leenellett EE. Relationship between bone growth rate and hypertrophic chondrocyte volume in New Zealand white rabbits of varying ages. J Orthop Res. 1996;14:706-11.

27. D'Ambrosio E, Casa B, Bompani R, Scali M, Scali G. Glucosamine sulphate: a controlled clinical investigation in arthrosis. Pharmacotherapeutica. 1981;2:504-8. 
28. Anderson JW, Nicolosi RJ, Borzelleca JF. Glucosamine effects in humans: a review of effects on glucose metabolism, side effects, safety considerations and efficacy. Food Chem Toxicol. 2005;43:187-201.

29. Bruyere O, Pavelka K, Rovati LC, Deroisy R, Olejarova M, Gaterovva $\mathrm{J}$, et al. Glucosamine sulfate reduces osteoarthritis progression in postmenopausal women with knee osteoarthritis: evidence from two 3year studies. Menopause. 2004;11:138-43.

30. Pavasant P, Shizari T, Underhill CB. Hyaluronan contributes to the enlargement of hypertrophic lacunae in the growth plate. J Cell Sci. 1996;109:327-34.
31. Wang SX, Cherian A, Dumitriu M, Grynpas MD, Carran J, Wainman D, et al. disease modifying effects of n-butyryl glucosamine in a streptococcal cell wall induced arthritis model in rats. J Rheumatol. 2007;34:654-7.

32. Chan PS, Caron JP, Orth MW. Effect of glucosamine and chondroitin sulfate on regulation of gene expression of proteolytic enzymes and their inhibitors in interleukin-1-challenged bovine articular cartilage explants. Am J Vet Res. 2005;66:1870-6.

33. Nakamura H, Shibakawa A, Tanaka M, Kato T, Nishioka K. Effects of glucosamine hydrochloride on the production of prostaglandin E2, nitric oxide and metalloproteases by chondrocytes and synoviocytes in osteoarthritis. Clin Exp Rheumatol. 2004;22:293-9. 